\begin{tabular}{cc|c}
\hline Tar. Bil. Der. & Tarm Bilimleri Dergisi & Journal of Agricultural Sciences \\
& $\begin{array}{c}\text { Dergi web sayfası: } \\
\text { www.agri.ankara.edu.tr/dergi }\end{array}$ & Journal homepage: \\
& www.agri.ankara.edu.tr/journal
\end{tabular}

\title{
Improvement Storability of 'Angeleno' Plum with the Combination of 1-Methylcyclopropene Treatment and Controlled Atmosphere Storage
}

\author{
Derya ERBAŞ̧, Mehmet Ali KOYUNCU ${ }^{\mathrm{a}}$, Fatma KOYUNCU ${ }^{\mathrm{a}}$ \\ "Isparta University of Applied Sciences, Faculty of Agricultural Sciences and Technologies, Deparment of Horticulture, 32260, Isparta, TURKEY
}

\section{ARTICLE INFO}

Research Article

DOI : 10.15832 /ankutbd.342949

Corresponding Author: Derya ERBAŞ, E-mail: deryaerbas@isparta.edu.tr, Tel: +90 (246) 2118509

Received: 11 October 2017, Received in Revised Form: 28 November 2017, Accepted: 29 November 2017

\begin{abstract}
The combined effects of postharvest 1-methylcyclopropene (1-MCP) treatment and controlled atmosphere (CA) storage on storage life and quality of 'Angeleno' (Prunus salicina Lindl.) plum were investigated after being treated with 1-MCP $\left(625 \mathrm{ng} \mathrm{g}^{-1}\right)$ at room temperature for $12 \mathrm{~h}$. Following the treatment, fruit were stored in normal atmosphere (NA) and CA $\left(1 \% \mathrm{O}_{2}-3 \% \mathrm{CO}_{2}\right)$ at $0{ }^{\circ} \mathrm{C}$ and $90 \pm 5 \%$ relative humidity for $120 \mathrm{~d}$. Fruit firmness, weight loss, respiration rate, ethylene production, soluble solid content, titratable acidity, fruit skin color and sensorial evaluation (external appearance, taste and chilling injury) were performed at harvest date and one month intervals during storage. Only 1-MCP treatment delayed the change in properties related to fruit ripening such as fruit softening, decrease in titratable acidity and increase in soluble solid content. Nevertheless, these effects were significantly higher when 1-MCP-treated plums were stored in CA conditions. The highest color change was found in NA conditions. 'Angeleno' plum stored in CA conditions gave the best results in terms of some quality parameters during storage. The combination of 1-MCP and CA storage prolonged storage life of 'Angeleno' plum compared to other treatments. These result demonstrated that the postharvest 1-MCP treatment can be used in the cold storage of Angeleno plums.
\end{abstract}

Keywords: Firmness; Postharvest treatment; Prunus salicina; Quality; SmartFresh

(C) Ankara Üniversitesi Ziraat Fakültesi

\section{Introduction}

Plum is a highly perishable climacteric fruit (Khan \& Singh 2009) and postharvest softening is a major factor limiting the storage period (Menniti et al 2006). Fruit softening, induced by ripening, is partially controlled by endogenous ethylene biosynthesis (Abdi et al 1997). Ethylene can profoundly affect quality of harvested fruit and these effects can be beneficial or deleterious depending on fruit (Watkins 2006).

Removing ethylene from storage rooms is generally beneficial in maintaining fruit quality and extending storage life. As in other climacteric species, ethylene triggers softening, an increase in soluble solids content, a decrease in titratable acidity (Larrigaudière et al 2009). Climacteric fruit such as plums ripen quickly and decay before they reach their market. Some of the strategies reported to retard metabolic changes and to improve storage life and quality in plum, includes: lowering the storage temperature, modifying air composition, stored at controlled atmosphere (CA) conditions (reducing $\mathrm{O}_{2}$ and increasing $\mathrm{CO}_{2}$ concentrations) and inhibition of ethylene production (Khan \& Singh 2009). However these strategies may be limited because of the appearance of storage 
disorders. Apricots and plums develop two main types of physiological storage disorders, internal browning and gel breakdown (Jooste \& Taylor 1999). Menniti et al (2006) indicated that CA storage is beneficial in extending the postharvest life of plums, but its benefits may be limited by the physiological disorders such as internal breakdown and gel breakdown, attributed to chilling injury (CI). Chilling injury manifests itself as browning of the flesh due to the enzyme oxidation of polyphenols and tannins (Dodd 1984). Plums with CI show no visible external changes, making the disorder difficult to detect. On account of these problems, treatments with 1-MCP and CA storage or combination of these are exciting strategies for controlling ethylene production and thus extending post-harvest storage life and reducing quality losses of fruit (Menniti et al 2006; Watkins 2006). 1-MCP and CA generally are more effective when used in combination.

At standard temperature and pressure 1-MCP is a gas (Blankeship \& Dole 2003) with a molecular weight of 54 and a formula of $\mathrm{C}_{4} \mathrm{H}_{6}$ (Özkaya et al 2007). This material is nontoxic, odorless, and compared with ethylene; 1-MCP is active at much lower concentrations (Jeong et al 2003). 1- MCP is thought to interact with ethylene receptors and thus block ethylene-dependent responses (Serek et al 1994). The affinity of 1-MCP for the receptor is approximately 10 times greater than that of ethylene (Blankenship \& Dole 2003). The effect of 1-MCP on postharvest life of fruit is bidirectional. First, it provides the potential to maintain fruit quality after harvest. Second, 1-MCP provides a powerful tool to gain insight into the fundamental processes that are involved in ripening and senescence (Watkins 2006). Many trials have been carried out to determine the effects of $1-\mathrm{MCP}$ on postharvest behavior of different fruit and quality losses. 1-MCP has been found to inhibit the action of ethylene and thereby extend the storage life of a range of fruit such as plum (Abdi et al 1998) and apple (Fan et al 1999) and apricot (Fan et al 2000). 'Angeleno' plums are harvested in the late season and have a short postharvest life compared to other climacteric fruit such as apples and pears. Improving postharvest life would increase the marketing period of this late season cultivar. The objective of this research was to determine the combined effect of 1-MCP treatment and CA storage on the storage life and quality of 'Angeleno' plums during storage.

\section{Material and Methods}

\subsection{Plant material, storage conditions and 1-MCP treatments}

The experiment was conducted on 8-year-old plum (Prunus salicina Lindl. cv. Angeleno) trees in Isparta-Turkey. Trees were grafted on Myrobalan (Prunus cerasifera Ehrh.) rootstock. Uniform trees free from pests and diseases were selected and all the experimental trees have similar cultural practices. Fruit were harvested according to fruit firmness and soluble solids content and carried to laboratory immediately. Plums were selected for uniformity of size and mass, and precooled by forced cold air. After precooling, plums were exposed to four different treatments $(100 \mathrm{~kg}$ plums in each group): 1. Fruit without 1-MCP treatment were stored in normal (air) atmosphere (NA) conditions (NA/Control); 2. Fruit were treated with 1-MCP $\left(625 \mathrm{ng} \mathrm{g}^{-1}\right)$ at room temperature for $12 \mathrm{~h}$ and then stored in NA conditions (NA/1$\mathrm{MCP}$ ); 3. Fruit without 1-MCP treatment were stored in $\mathrm{CA}\left(1 \% \mathrm{O}_{2}-3 \% \mathrm{CO}_{2}\right)$ conditions $(\mathrm{CA} /$ Control); 4. Fruit were treated with 1-MCP (625 $\left.\mathrm{ng} \mathrm{g}^{-1}\right)$ at room temperature for $12 \mathrm{~h}$ and then stored in $\mathrm{CA}\left(1 \% \mathrm{O}_{2}-3 \% \mathrm{CO}_{2}\right)$ conditions $(\mathrm{CA} / 1-\mathrm{MCP})$. For the 1-MCP treatment, the plastic boxes were covered with a $1 \mathrm{~m}^{3}$ polyethylene bag in a gastight chamber. The treatment was carried out using the device provided by SmartFresh Company that consists of a small ventilator and reaction mixture. To obtain $625 \mathrm{ng} \mathrm{g}^{-1}$ (commercial dose on most of the commodities) 1-MCP in polyethylene bag, the reaction mixture contained $15 \mathrm{~mL}$ activator solution, 2 tablets of activator and 2 tablets of 1-MCP. Fruit were exposed to $625 \mathrm{ng} \mathrm{g}^{-1} 1-\mathrm{MCP}$ at room temperature for $12 \mathrm{~h}$. After 1-MCP treatment, the polyethylene bag was opened and ventilated. Fruit in all treatments were stored at 0 ${ }^{\circ} \mathrm{C}$ and $90 \pm 5 \%$ relative humidity for $120 \mathrm{~d}$, and the following analyses were performed initially and one month intervals during storage. 


\subsection{Chemical and physical analysis}

Fruit flesh firmness was measured over 15 fruit in each replicate. Fruit firmness was determined using a digital texture machine (Lloyd Instruments LF Plus) and measured via compression using a 50 $\mathrm{N}$ load cell and a stainless steel, $5.1 \mathrm{~mm}$ diameter cylindrical probe (Martinez-Romero et al 2003; Serrano et al 2003; Luo et al 2009) with a constant speed of $100 \mathrm{~mm} \mathrm{~min}^{-1}$ at harvest date and during storage period. The maximum force generated during the probe travel was used for data analysis. The results were expressed as Newton $(\mathrm{N})$.

Weight loss of plums was measured over 15 fruit in each replicate and expressed as the percentage of loss of weight with respect to the initial weight. Weight loss was determined by the Equation;

Weight loss $=[($ First weight - Last weight $) /$ First weight $] \times 100$

Respiration rate and ethylene production were measured in 750-800 $\mathrm{g}$ of fruit samples for each replicate. Fruit were weighed and placed in $4 \mathrm{~L}$ airtight jars for $24 \mathrm{~h}$ at $20^{\circ} \mathrm{C}$. Then gas sample was taken from jars and injected into gas chromatographs. Measurements were made in split/splitless (S/SL) of inlet in split mode with gas sampling valve with 1 $\mathrm{mL}$ gas sample by using fused silica capillary column (GS-GASPRO, $30 \mathrm{~m} \times 0.32 \mathrm{~mm}$ I.D., U.S.A), with thermal conductivity detector (TCD) for respiration rate measurements and flame ionization detector (FID) for ethylene production measurements by Agilent GC-6890N (U.S.A and Canada) model gas chromatography (GC) and Chemstation A.09.03 [1417] software. Carrier gas (helium) flow was 1.7

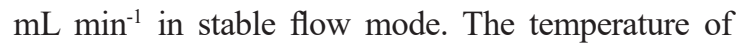
the oven, TCD and FID detectors were $250{ }^{\circ} \mathrm{C}$ and $250{ }^{\circ} \mathrm{C}$, respectively. Results were expressed as $\mu \mathrm{L}$ $\mathrm{kg}^{-1} \mathrm{~h}^{-1}$ for ethylene production and $\mathrm{mL} \mathrm{CO} \mathrm{Kg}^{-1}$ $\mathrm{h}^{-1}$ for respiration rate. Total soluble solids (TSS) content was measured using a digital refractometer (Atago Pocket PAL-1) and expressed as percentage. Titratable acidity (TA) was determined by a digital pH meter (Hanna Instruments HI 9231) and titrimeter (Digitrat, Isolab), and expressed as percentage of grams of malic acid equivalent per kg fresh weight ( $\mathrm{g}$ $\left.\mathrm{kg}^{-1}\right)$. Fruit skin color was determined using a Minolta CR-300 colorimeter (Minolta Ramsey, NJ, USA) over 15 fruit in each replicate. Minolta color measurement apparatus was calibrated according to the standard white calibration plate $(\mathrm{Y}=92.3, \mathrm{x}=0.3136$ and $y=0.3194)$. The values were expressed by the CIE $L^{*}$ (brightness-darkness), $\mathrm{a}^{*}\left(+\mathrm{a}^{*}\right.$ : red, $-\mathrm{a}^{*}$ : green) and $\mathrm{b}^{*}$ $\left(+b^{*}\right.$ : yellow, $-b^{*}:$ blue $)$ system and the values were evaluated as $\mathrm{L}^{*}$, chroma $\left(\mathrm{C}^{*}\right)$ and hue angle $\left(\mathrm{h}^{\mathrm{o}}\right)$.

$\mathrm{h}^{\mathrm{o}}=\tan ^{-1}\left(\mathrm{~b}^{*} / \mathrm{a}^{*}\right) \mathrm{C}^{*}=\left[\left(\mathrm{a}^{*}\right)^{2}+\left(\mathrm{b}^{*}\right)^{2}\right]^{1 / 2}$

External appearance was rated on a hedonic scale of 1-9 ( $\leq 1-4$ : poor, $\geq 5$ : marketable, 7-8: good, 9: excellent) and taste was rated on a hedonic scale of 1-5 (1: very poor, 2: poor, 3 : mild, 4: good, 5: excellent). The internal translucency and browning symptoms which affect fruit quality visually were recorded, and expressed as an index of chilling injury (CI). The scale of CI was defined visually according to the percentage of affected pulp and where: Grade 1 was $25 \%$, grade 2 was 25 to $50 \%$, grade 3 was 50 to $75 \%$ and grade 4 was $75 \%$ (Candan et al 2006).

CI index $=\sum$ (Grade of intensity $\times$ Number of fruit at this grade) / total fruit

The experiment was set up according to the completely factorial randomized design with 3 replications. Main effects and interactions were analyzed and means were compared by Tukey's Tests at a significance level of 0.05 (Table 1). All analyses were performed with SPSS software package v.18.0 for Windows by General Linear Model (GLM) univariate test.

\section{Results}

\subsection{Effect of treatments on weight loss during storage}

The weight losses of plums during storage period were illustrated in Figure 1. The interaction effects between treatments and storage period for weight loss were significant $(\mathrm{P}<0.05)$. The weight loss of plums increased steadily with prolonged storage period in 
Table 1- Anova for dependent variables for treatments, storage period and their interactions

\begin{tabular}{lllllllllllll}
\hline & $W L$ & $F F$ & $E P$ & $R R$ & $T S S$ & $T A$ & $L^{*}$ & $C^{*}$ & $h^{\circ}$ & $T$ & $E E$ & $C I$ \\
\hline $\mathrm{Tr}$ & $* *$ & $* *$ & $* *$ & $* *$ & $* *$ & $* *$ & $* *$ & $\mathrm{NS}$ & $\mathrm{NS}$ & $* *$ & $* *$ & $* *$ \\
$\mathrm{SP}$ & $* *$ & $* *$ & $* *$ & $* *$ & $* *$ & $* *$ & $*$ & $*$ & $\mathrm{NS}$ & $* *$ & $* *$ & $* *$ \\
$\mathrm{Tr} \times \mathrm{SP}$ & $*$ & $* *$ & $* *$ & $*$ & $*$ & $*$ & $\mathrm{NS}$ & $\mathrm{NS}$ & $\mathrm{NS}$ & $* *$ & $* *$ & $* *$ \\
\hline
\end{tabular}

${ }_{\mathrm{NS}}$, represents non-significance at $\mathrm{P}<0.05 ; * *$, represents significance at the 0.01 level; $*$, represents significance at the 0.05 level; $\mathrm{Tr}$, ,reatments; SP, storage period; WL, weight loss; FF, fruit firmness; EP, Ethylene production; RR, respiration rate; TSS, total soluble solid; TA, titratable acidity; $\mathrm{C}^{*}, \mathrm{Chroma} \mathrm{h}^{\circ}$, hue angle; $\mathrm{T}$, taste; EE, external appearance; $\mathrm{CI}$, chilling injury

A

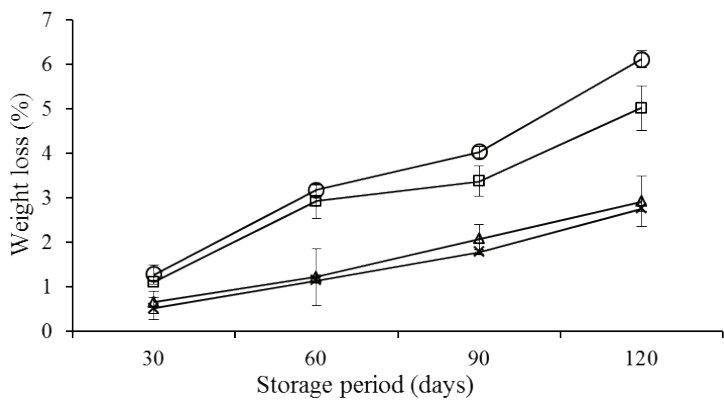

C $\rightarrow \mathrm{NA} /$ Control $\square-\mathrm{NA} / 1-\mathrm{MCP} \triangle \mathrm{CA} / \mathrm{Control} \rightarrow \mathrm{CA} / 1-\mathrm{MCP}$

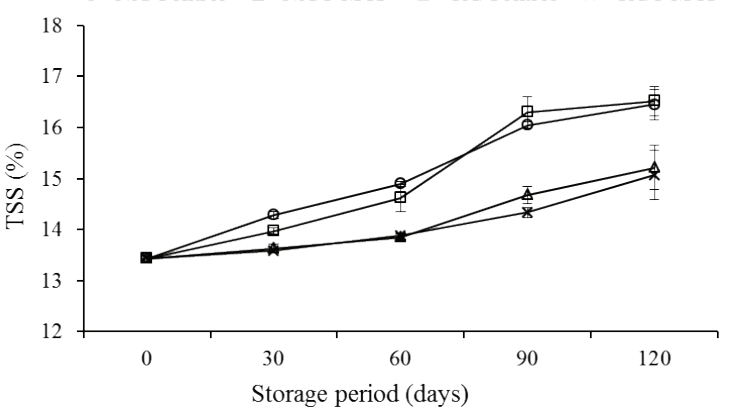

B $-\mathrm{NA} / \mathrm{Control} \square \mathrm{NA} / 1-\mathrm{MCP} \triangle \mathrm{CA} /$ Control $\rightarrow \mathrm{CA} / 1-\mathrm{MCP}$

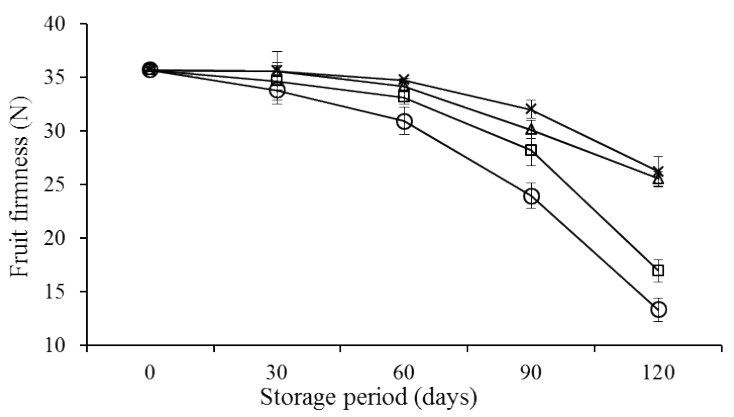

$\mathrm{D} \rightarrow \mathrm{NA} / \mathrm{Control} \square-\mathrm{NA} / 1-\mathrm{MCP} \rightarrow \mathrm{CA} / \mathrm{Control} \rightarrow \mathrm{CA} / 1-\mathrm{MCP}$

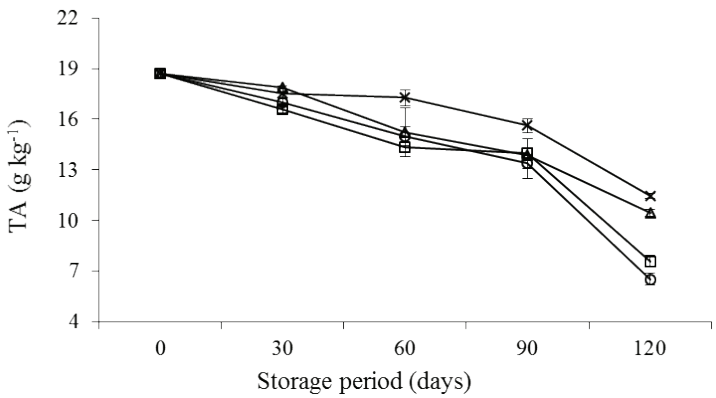

Figure 1- Weight loss (A), fruit firmness (B) total soluble solids content (TSS) (C) and titratable acidity (TA) (D) of plum cv. Angeleno during storage

all treatments. Weight loss in 1-MCP-treated fruit was less compared to the control fruit in NA and $\mathrm{CA}$ conditions. The combination of $1-\mathrm{MCP}$ and $\mathrm{CA}$ gave the lowest $(2.75 \%)$ weight loss after $120 \mathrm{~d}$ cold storage whereas the highest weight loss $(6.11 \%)$ was obtained from control fruit stored in air.

\subsection{Effect of treatments on fruit firmness during storage}

The changes of fruit firmness observed in treated and control fruit during the storage period were given on the Figure 1. The interaction effects between treatment and storage period for fruit firmness were significant $(\mathrm{P}<0.01)$. In all treatments, the firmness of plums decreased with increasing storage periods. The amount of decrease in 1-MCP-treated fruit was less than that of non-treated fruit. The combination of 1-MCP and CA was more effective to maintain fruit firmness compared to other treatments. While fruit firmness at harvest was $35.68 \mathrm{~N}$, the control group fruit in NA displayed the highest firmness loss $(13.29 \mathrm{~N})$, followed by NA+1-MCP $(16.93 \mathrm{~N})$, 
CA/Control $(25.52 \mathrm{~N})$ and CA/1-MCP $(26.19 \mathrm{~N})$ treatments, respectively at the end of the storage period (Figure 1).

\subsection{Effect of treatments on TSS content and TA during storage}

The TSS and TA of plums during the storage period were illustrated in Figure 1. All treatment displayed an increase in TSS of plums during storage. Control group in NA had the highest TSS (15.02\%) while the lowest value $(14.06 \%)$ was obtained from fruit treated with 1-MCP, and stored in CA. The TSS of 1-MCP-treated plums was lower than those of non-treated plums in both conditions. On the contrary of the TSS values, the TA of 1-MCP-treated plums $\left(14.25 \mathrm{~g} \mathrm{~kg}^{-1}\right.$ in NA$16.13 \mathrm{~g} \mathrm{~kg}^{-1}$ in CA) was higher than those of control groups (14.13 $\mathrm{g} \mathrm{kg}^{-1}$ in NA-15.23 $\mathrm{g} \mathrm{kg}^{-1}$ in CA). The best results in terms of TA also were obtained from the combination of 1-MCP and CA.

\subsection{Effect of treatments on ethylene production and respiration rate during storage}

For the plums stored in CA as well as in NA, the ethylene production increased with increasing storage periods. The effect of the 1-MCP treatments was more effective than that of the control groups. In NA conditions, the ethylene production of control fruit was $1.18 \mu \mathrm{L} \mathrm{kg}^{-1} \mathrm{~h}^{-1}$ while this value was obtained as $0.65 \mu \mathrm{L} \mathrm{kg}^{-1} \mathrm{~h}^{-1}$ for the 1-MCP-treated plums. Generally, fruit under CA had lower ethylene production than those of NA. Plums treated with 1-MCP and stored in CA had the lowest ethylene production $\left(0.37 \mu \mathrm{L} \mathrm{kg}^{-1} \mathrm{~h}^{-1}\right)$ followed by control group of CA $\left(0.43 \mu \mathrm{L} \mathrm{kg}^{-1} \mathrm{~h}^{-1}\right)$.

The respiration rates of plums were higher at the end of storage compared to initial values in all conditions. 1-MCP-treated fruit had lower respiration rates than those of control groups in NA and CA. Especially, the combination of 1-MCP and $\mathrm{CA}$ was determined to be the most effective treatment for the suppression of respiration rate $\left(4.65 \mathrm{~mL} \mathrm{CO}_{2}\right.$ $\mathrm{kg}^{-1} \mathrm{~h}^{-1}$ ) as well as ethylene production (Figure 2).

\subsection{Effect of treatments on fruit skin color during storage}

In all treatments, $L^{*}$ values of plums decreased at the end of storage period compared to initial values. $L^{*}$ value, representing brightness, of fruit treated with 1-MCP and stored in CA was the highest (25.30), while the lowest value was obtained from 1-MCPtreated fruit in NA (23.67). Considering the $\mathrm{C}^{*}$ values, 1-MCP-treated plums in CA storage gave higher values than those of the other treatments. Plums stored in CA had limited changes in $\mathrm{C}^{*}$ values according to fruit kept in NA. During storage, hue angle decreased in NA, while these values increased in CA (Table 2).

\subsection{Effect of treatments on external appearance, taste and chilling injury during storage}

The changes in fruit external appearance, taste and chilling injury observed in 1-MCP-treated and nontreated fruit during the storage period (NA and $\mathrm{CA}$ ) were given in Table 3. The external appearance
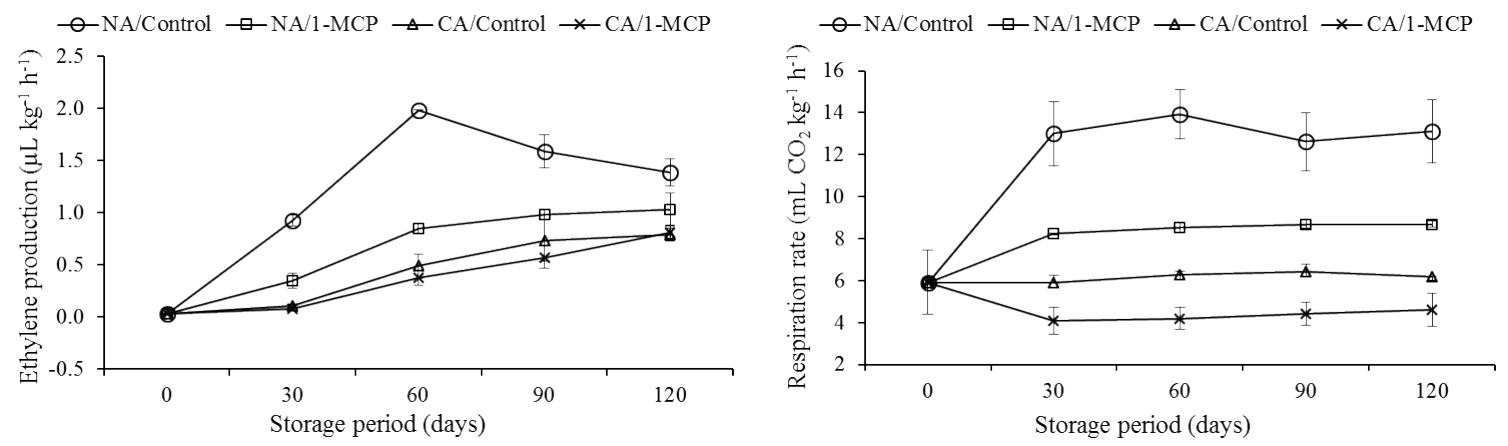

Figure 2- Ethylene production (A) and respiration rate (B) of plum cv. Angeleno during storage 
Table 2- $\mathrm{L}^{*}$, chroma $\left(\mathrm{C}^{*}\right)$ and hue angle $\left(\mathrm{h}^{\circ}\right)$ values of plum $\mathrm{cv}$. Angeleno during storage

\begin{tabular}{|c|c|c|c|c|c|c|}
\hline \multicolumn{7}{|l|}{$L^{*}$} \\
\hline Treatments & 0 & 30 & 60 & 90 & 120 & Means \\
\hline NA/Control & $25.35 \pm 0.27$ & $24.22 \pm 0.16$ & $23.52 \pm 0.32$ & $23.07 \pm 0.57$ & $22.80 \pm 0.11$ & $23.79 b^{*}$ \\
\hline NA/1-MCP & $25.80 \pm 0.35$ & $23.40 \pm 0.33$ & $23.45 \pm 0.42$ & $22.32 \pm 0.38$ & $23.38 \pm 0.17$ & $23.67 b$ \\
\hline CA/Control & $25.59 \pm 0.19$ & $25.18 \pm 1.13$ & $25.51 \pm 0.65$ & $24.90 \pm 0.45$ & $25.07 \pm 0.49$ & $25.25 a$ \\
\hline CA/1-MCP & $25.65 \pm 0.32$ & $25.02 \pm 1.95$ & $25.40 \pm 0.75$ & $25.30 \pm 0.80$ & $25.11 \pm 0.37$ & $25.30 a$ \\
\hline Means & $25.60 \mathrm{a}^{*}$ & $24.45 \mathrm{ab}$ & $24.47 \mathrm{ab}$ & $23.90 \mathrm{~b}$ & $24.09 \mathrm{~b}$ & \\
\hline \multicolumn{7}{|l|}{$C^{*}$} \\
\hline NA/Control & $11.26 \pm 0.20$ & $7.97 \pm 0.88$ & $10.14 \pm 0.46$ & $9.97 \pm 0.93$ & $8.99 \pm 0.27$ & $9.66^{n s^{* *}}$ \\
\hline NA/1-MCP & $10.68 \pm 0.28$ & $8.79 \pm 0.46$ & $9.84 \pm 0.66$ & $10.03 \pm 0.14$ & $8.67 \pm 0.53$ & 9.60 \\
\hline CA/Control & $10.79 \pm 0.50$ & $9.83 \pm 0.33$ & $10.43 \pm 0.62$ & $10.13 \pm 0.45$ & $9.39 \pm 0.13$ & 10.11 \\
\hline CA/1-MCP & $11.07 \pm 0.23$ & $10.09 \pm 3.11$ & $10.36 \pm 0.36$ & $10.18 \pm 0.28$ & $9.79 \pm 0.27$ & 10.30 \\
\hline Means & $10.95 \mathrm{a}^{*}$ & $9.17 \mathrm{~b}$ & $10.19 \mathrm{ab}$ & $10.08 \mathrm{ab}$ & $9.21 \mathrm{~b}$ & \\
\hline \multicolumn{7}{|l|}{$h^{\circ}$} \\
\hline NA/Control & $21.59 \pm 0.72$ & $24.23 \pm 5.22$ & $19.47 \pm 0.47$ & $18.42 \pm 0.92$ & $19.90 \pm 0.73$ & $20.72^{n s}$ \\
\hline NA/1-MCP & $23.93 \pm 5.94$ & $19.31 \pm 2.34$ & $18.54 \pm 0.39$ & $20.57 \pm 0.46$ & $21.70 \pm 1.37$ & 20.81 \\
\hline CA/Control & $18.76 \pm 1.83$ & $21.27 \pm 1.43$ & $22.46 \pm 2.48$ & $23.09 \pm 2.05$ & $20.86 \pm 0.77$ & 21.29 \\
\hline CA/1-MCP & $19.83 \pm 3.55$ & $21.27 \pm 7.03$ & $19.73 \pm 0.52$ & $19.88 \pm 0.32$ & $22.36 \pm 1.62$ & 20.61 \\
\hline Means & $21.03^{\mathrm{ns}}$ & 21.52 & 20.05 & 20.49 & 21.20 & \\
\hline
\end{tabular}

and taste scores of plums decreased depending on the length of storage period. However, there was a positive effect of 1-MCP treatment on external appearance and taste of fruit compared to control treatments. With the prolonged storage life, there was a continuous increase in CI during the storage.

Table 3- Taste, external appearance and chilling injury of plum cv. Angeleno during storage

\begin{tabular}{|c|c|c|c|c|c|c|}
\hline \multicolumn{7}{|c|}{ Taste (1-5 scale) } \\
\hline Treatments & 0 & 30 & 60 & 90 & 120 & Means \\
\hline NA/Control & $5.00 \pm 0.00 \mathrm{a}^{*}$ & $4.56 \pm 0.11 \mathrm{ab}$ & $3.28 \pm 011 \mathrm{~d}$ & $1.83 \pm 0.17$ ef & $1.33 \pm 0.17 \mathrm{f}$ & 3.20 \\
\hline NA/1-MCP & $5.00 \pm 0.00 \mathrm{a}$ & $4.72 \pm 0.15 \mathrm{a}$ & $3.67 \pm 0.10 \mathrm{~cd}$ & $2.06 \pm 0.06 \mathrm{e}$ & $1.22 \pm 0.05 \mathrm{f}$ & 3.33 \\
\hline CA/Control & $5.00 \pm 0.00 \mathrm{a}$ & $4.89 \pm 0.06 \mathrm{a}$ & $4.44 \pm 0.06 \mathrm{ab}$ & $3.44 \pm 0.06 \mathrm{~cd}$ & $1.61 \pm 0.20 \mathrm{ef}$ & 3.88 \\
\hline CA/1-MCP & $5.00 \pm 0.00 \mathrm{a}$ & $5.00 \pm 0.00 \mathrm{a}$ & $4.83 \pm 0.1 \mathrm{a}$ & $3.94 \pm 0.06 \mathrm{bc}$ & $1.50 \pm 0.29$ ef & 4.06 \\
\hline Means & 5.00 & 4.79 & 4.06 & 2.82 & 1.42 & \\
\hline \multicolumn{7}{|c|}{ External appearance (1-9 scale) } \\
\hline NA/Control & $9.00 \pm 0.00 \mathrm{a}^{*}$ & $8.89 \pm 0.06 \mathrm{a}$ & $6.28 \pm 0.31 \mathrm{~d}$ & $4.17 \pm 0.10 \mathrm{e}$ & $2.06 \pm 0.06 \mathrm{f}$ & 6.08 \\
\hline NA/1-MCP & $9.00 \pm 0.00 \mathrm{a}$ & $9.00 \pm 0.00 \mathrm{a}$ & $6.72 \pm 0.43 \mathrm{~cd}$ & $4.17 \pm 0.17 \mathrm{e}$ & $2.67 \pm 0.35 \mathrm{f}$ & 6.31 \\
\hline CA/Control & $9.00 \pm 0.00 \mathrm{a}$ & $9.00 \pm 0.00 \mathrm{a}$ & $7.78 \pm 0.11 \mathrm{~b}$ & $6.56 \pm 0.06 \mathrm{~cd}$ & $4.22 \pm 0.11 \mathrm{e}$ & 7.31 \\
\hline CA/1-MCP & $9.00 \pm 0.00 \mathrm{a}$ & $9.00 \pm 0.00 \mathrm{a}$ & $8.17 \pm 0.17 \mathrm{ab}$ & $7.28 \pm 0.31 \mathrm{~b}$ & $4.06 \pm 0.06 \mathrm{e}$ & 7.50 \\
\hline Means & 9.00 & 8.97 & 7.24 & 5.54 & 3.25 & \\
\hline \multicolumn{7}{|c|}{ Chilling injury (0-4 scale) } \\
\hline NA/Control & $0.00 \pm 0.00 \mathrm{~g}$ & $0.07 \pm 0.04 \mathrm{~g}$ & $0.38 \pm 0.15 \mathrm{fg}$ & $1.78 \pm 0.22 \mathrm{~cd}$ & $3.58 \pm 0.16 \mathrm{a}$ & 1.16 \\
\hline NA/1-MCP & $0.00 \pm 0.00 \mathrm{~g}$ & $0.04 \pm 0.04 \mathrm{~g}$ & $0.49 \pm 0.25 \mathrm{fg}$ & $1.40 \pm 0.14 \mathrm{de}$ & $2.49 \pm 0.25 \mathrm{~b}$ & 0.88 \\
\hline CA/Control & $0.00 \pm 0.00 \mathrm{~g}$ & $0.00 \pm 0.00 \mathrm{~g}$ & $0.23 \pm 0.03 \mathrm{~g}$ & $1.16 \pm 0.12 \mathrm{de}$ & $2.27 \pm 0.07 \mathrm{bc}$ & 0.73 \\
\hline CA/1-MCP & $0.00 \pm 0.00 \mathrm{~g}$ & $0.00 \pm 0.00 \mathrm{~g}$ & $0.09 \pm 0.06 \mathrm{~g}$ & $0.92 \pm 0.01 \mathrm{ef}$ & $1.37 \pm 0.09 \mathrm{de}$ & 0.48 \\
\hline Means & 0.00 & 0.03 & 0.30 & 1.31 & 2.43 & \\
\hline
\end{tabular}

*, means with different letters are statistically significant at $\mathrm{P}<0.05, \mathrm{n}=3$, Tukey. External appearance scale, 1-9 ( $\leq 1-4:$ poor, $\geq 5$ : marketable, 7-8: good, 9: excellent); Taste scale, 1-5 (1: very poor, 2: poor, 3: mild, 4: good, 5: excellent); Chilling injury index, Grade 1 was $25 \%$, Grade 2 was 25 to $50 \%$, Grade 3 was 50 to $75 \%$ and Grade 4 was $75 \%$ 
The amount of increase in 1-MCP-treated fruit $(0.88 \%$ in NA $-0.48 \%$ in $\mathrm{CA})$ was less than those of non-treated fruit $(1.16 \%$ in NA - $0.73 \%$ in $\mathrm{CA})$.

\section{Discussion}

Weight loss of fruit can lead to shriveling which reduces both market value and consumer acceptability. As expected in this research, higher weight loss in NA condition is related to higher water vapor losses depending on evaporation. Less weight loss in plums treated with 1-MCP and stored in CA may be due to retarded senescence and constant relative humidity of CA compared to NA. In addition, it was thought that the higher weight loss in NA, especially after 60 days of storage, related to lower relative humidity of NA condition. Manganaris et al (2008) reported that 1-MCP treatment could have a modified epicuticular wax metabolism as the cuticle acts as a barrier to vapor movement from inside the cuticle or delay changes epicuticular waxes that occur during senescence.

The textural change is one of the most important features during fruit ripening and affects postharvest life of fruit (Luo et al 2009) and can cause a significant reduction in quality during postharvest life (Salvador et al 2003). The explanation for the firmness maintenance of 'Angeleno' plum in CA (Figure 2) could be related to maintain the integrity of cell wall pectin and low weight losses. Rapid softening of plums in NA (Figure 2) can be due to high ethylene production of fruit in this condition. Similarly, Menniti et al (2004) showed that plum cultivars with high rates of ethylene production softened and ripened faster than low ethylene producing cultivars. The positive effect of the combination of 1-MCP with CA storage on fruit firmness was determined in our study as well. Our results agreed with some previous reports that 1-MCP and CA maintained fruit firmness of plums compared to control groups (Candan et al 2006; Menniti et al 2006). Ethylene production is necessary for a normal ripening process in all plums. Storage techniques, such as CA, which inhibit ethylene production, have been shown to improve post-storage quality of stone fruit (Kader et al 1982).
This study showed that the ethylene production was lower in CA than that of NA conditions (Figure 2). Similarly, Pretel et al (1999) and Thompson (2010) reported that fruit had a lower respiration rates and ethylene production during CA storage compared to air storage. The effectiveness of the 1-MCP and $\mathrm{CA}$ on the inhibition of ethylene production and respiration rate was clear. Findings of this research are accordance with those of Luo et al (2009) and Valero et al (2004).

Soluble solid content includes reducing and non-reducing sugars, organic acids, and other soluble metabolites (Salisbury \& Ross 1985). TSS increased gradually with ripening of plums during storage period. The increase of TSS can be due to reducing water content of plums. A greater increasing in TSS (Figure 1) was determined, as expected, at NA conditions (treated and non-treated plum) because of the higher weight loss (Figure 1). Likewise, according to Kluge et al (1996), sugar loss due to respiration could account for sugar increases with weight loss. As shown in Figure 1, the increase of TSS and the fall in TA were significantly inhibited by 1-MCP and CA. The loss of acidity occurred rapidly in NA conditions compared to CA conditions especially, the combination of 1-MCP with CA. Similar results were found by Manganaris et al (2008) and Diaz-Mula et al (2009). Skin color of plums changed from deep purple to dark black during the storage. This change was delayed in all fruit treated with 1-MCP (Table 2), as has been previously reported by Valero et al (2003) and Manganaris et al (2008) in plums. The positive effect of CA storage on the color difference of fruit was determined in this study, and these findings seem to be a general effect of CA in delaying the fruit ripening process during storage. Results of this study are similar to the findings by Crisosto \& Kader (2000), who reported that one of the major benefits of CA storage are delay of color changes. As expected, the external appearance and taste scores of plums declined linearly with storage time. However, one of the most important physiological disorders of Japanese type plums, namely CI, increased with prolonging storage period. Similar 
to other quality parameters, the rate of CI was higher when plums were stored in NA conditions. However, CI development was also delayed by the combination with 1-MCP treatment and CA (Table $3)$. These results show that CA storage was able to delay the normal changes that occur during the postharvest ripening processes. Similarly, Kaynaş et al (2009) indicated that CI increased during storage duration, and the use of CA storage reduces CI (Macheix et al 1990).

\section{Conclusions}

As a result, according to many quality parameters, the combination of 1-MCP with CA was effective to extend the storability of 'Angeleno' plum compared to other treatment. As a non-phytotoxic, odorless and effective gas, 1-MCP could be a promising candidate for use in prolonging post-harvest life of ‘Angeleno’ plums.

\section{Acknowledgements}

We would like to thank SDU BAP (Project No: 1900-YL-09) to the financial support for this research project. This article was produced from the master's thesis of Derya ERBAŞ.

\section{References}

Abdi N, Holford P, McGlasson W B \& Mizrahi Y (1997). Ripening behavior and responses to propylene in four cultivars of Japanese type plums. Postharvest Biology and Technology 12(1): 21-34

Abdi N, McGlasson W B, Holford P \& Williams M (1998). Responses of climacteric and suppressedclimacteric plums to treatment with propylene and 1-methylcyclopropene. Postharvest Biology and Technology 14(1): 29-39

Blankenship S M \& Dole J M (2003). 1-Methylcyclopropene: A review. Postharvest Biology and Technology 28(1): $1-25$

Candan A P, Graell J, Crisosto C \& Larrigaudière $C$ (2006). Improvement of storability and shelf-life of 'Blackamber' plums treated with 1-methylcyclopropene. Food Science and Technology International 12(5): 437-443
Crisosto C H \& Kader A A (2000). Plum and fresh prune postharvest quality maintenance guidelines. Handbook of fruits and fruit processing. Ed. by. YH Hyi, pp. 553-554

Diaz-Mula H M, Zapata P J, Guillen F, Martinez-Romero D, Castillo S, Serrano M \& Valero D (2009). Changes in hydrophilic and lipophilic antioxidant activity and related bioactive compounds during postharvest storage of yellow and purple plum cultivars. Postharvest Biology and Technology 51(3): 354-363

Dodd M C (1984). Internal breakdown in plums. Deciduous Fruit Grower 34(8): 255-256

Fan X, Blankenship S M \& Mattheis J P (1999). 1-Methylcyclopropene inhibits apple ripening. Journal of the American Society for Horticultural Science 124(6): 690-695

Fan X, Argenta L \& Mathesis J P (2000). Inhibition of ethylene action by 1-MCP prolongs storage life of apricots. Postharvest Biology and Technology 20(2): 135-142

Jeong J, Huber D J \& Sargent S A (2003). Delay of avocado (Persea americana) fruit ripening by 1-methylcyclopropene and wax treatments. Postharvest Biology and Technology 28(2): 247-257

Jooste M M \& Taylor M A (1999). Effect of harvest maturity and cold storage period on the overall quality of 'Bebeco' apricots, with special reference to gel breakdown and varieties used to accurately establish harvest maturity. Deciduous Fruit Grower 49(1999): $1-10$

Kader A A, El-Goorani M A \& Sommer N F (1982). Postharvest decay, respiration, ethylene production, and quality of peaches held in controlled atmospheres with added carbon monoxide. Journal of the American Society for Horticultural Science 107(5): 856-859

Kaynaş K, Sakaldaş M \& Yurt U (2009). The effects of different postharvest applications and different modified atmosphere packaging types on fruit quality of Angeleno plums. Proceeding of the $10^{\text {th }}$ International Controlled and Modified Atmosphere Research Conference, 4-7 April 2009, Antalya, Turkey

Khan A S \& Singh Z (2009). 1-MCP application suppresses ethylene biosynthesis and retards fruit softening during cold storage of 'Tegan Blue' Japanese plum. Plant Science 176(4): 539-544

Kluge R A, Bilhalva A B \& Cantillano R F F (1996). Cold storage of Reubennel plums (Prunus salicina Lindl.): 
Effects of ripening stage and polyethylene packing. Scientia Agricola 53(2-3): 226-231

Larrigaudière C, Candan A P, Ubach D \& Graell J (2009). Physiological response of 'Larry Ann' plums to cold storage and 1-MCP treatment. Postharvest Biology and Technology 51(1): 56-61

Luo Z, Xie J, Xu T \& Zhang L (2009). Delay ripening of 'Qingnai' plum (Prunus salicina Lindl.) with 1-methylcyclopropene. Plant Science 177(6): 705709

Macheix J J, Fleuriet A \& Billot J (1990). Fruit Phenolics. CRC Press: Boca Raton FL, 392 pp

Manganaris G A, Crisosto C H, Bremer V \& Holcroft D (2008). Novel 1-methylcyclopropene immersion formulation extends shelf life of advanced maturity Joanna Red plums (Prunus salicina Lindell). Postharvest Biology and Technology 47(3): 429-433

Martinez-Romero D, Dupille E, Gullien F, Valverde J M, Serrano M \& Valero D (2003). 1-Methylcycloprone increases storability and shelf life in climacteric and nonclimacteric plums. Journal of Agricultural and Food Chemistry 51(16): 4680-4686

Menniti A M, Gregori R \& Donati I (2004). 1-Methylcyclopropene retards postharvest softening of plums. Postharvest Biology and Technology 31(3): 269-275

Menniti A M, Donati I \& Gregori R (2006). Response of 1-MCP application in plums stored under air and controlled atmospheres. Postharvest Biology and Technology 39(3): 243-246

Özkaya O, Dündar Ö \& Küden A (2007). Cold storage performance of Angeleno plum varieties grown in Adana conditions. III. Cold Storage and Marketing Symposium on Horticultural Crops, 6-9 September 2007, Mustafa Kemal University, Hatay, Turkey, pp. 406-408
Pretel M T, Serrano M, Amorós A \& Romojaro F (1999). Ripening and ethylene biosynthesis in controlled atmosphere stored apricots. European Food Research and Technology 209(2): 130-134

Salisbury F B \& Ross C W (1985). Plant Physiology. $3^{\text {th }}$ Ed. Wadsworth, Belmont, California

Salvador A, Cuquerella J \& Martinez-Javega J M (2003). 1-MCP treatment prolongs postharvest life of Santa Rosa plums. Journal of Food Science 68(4): 15041510

Serek M, Sisler E C \& Reid M S (1994). Novel gaseous ethylene binding inhibitor prevents ethylene effects in potted flowering plants. Journal of the American Society for Horticultural Science 119(6): 1230-1233

Serrano M, Martinez-Romero D, Guillen F \& Valero D (2003). Effects of exogenous on improving shelf life of four plum cultivars. Postharvest Biology and Technology 30(3): 259-271

Thompson A K (2010). Controlled Atmosphere Storage of Fruits and Vegetables. CAB International, 272, London

Valero D, Martinez-Romeo D, Valverde J M, Guillen F, Castillo S \& Serrano M (2003). Quality improvement and extension of the shelf life by 1methylcyclopropene in plum as affected by ripening stage at harvest. Innovative Food Science \& Emerging Technologies 4(3): 339-348

Valero D, Martinez-Romero D, Valverde J M, Guillen F, Castillo S \& Serrano M (2004). Could 1-MCP treatment effectiveness in plum be affected by packaging? Postharvest Biology and Technology 34(3): 295-303

Watkins C B (2006). The use of 1-methylcyclopropene (1-MCP) on fruits and vegetables. Biotechnology Advances 24(4): 389-409 